\title{
An RNA mystery and its denouement
}

\author{
DAVID A. BROW \\ Department of Biomolecular Chemistry, University of Wisconsin, Madison, Wisconsin 53706, USA
}

My graduate student Regina Vidaver and I published the first article in the second issue of RNA in April 1995. Our paper reported a surprising property of human U6 RNA that provides insight into mechanisms for modulating the stability of RNA-RNA complexes. That article represents the midpoint in my career in RNA science so far. Below I describe what led up to that article, and very briefly consider how things have changed since it was published.

I became a member of the RNA community in 1978, when I joined Harry Noller's research group at UC Santa Cruz as a junior undergraduate. At that time, entry into the Noller lab as an undergrad required satisfactory purification of a restriction enzyme (in my case SmaI) from a frozen wad of bacterial cells in his 182L Biochemistry of Macromolecules lab course. Having passed this hurdle, Harry assigned me the task of identifying contacts between tRNA and rRNA in the E. coli ribosome, using the guanine-specific reagent kethoxal as a probe.

Reverse transcriptase mapping of chemically modified bases had not yet been invented, so I labeled ribosomes in vivo with ${ }^{32} \mathrm{P}$ and identified modified residues via inhibition of RNase T1 digestion by the kethoxal adduct, a procedure Harry had devised. Mapping the sites required high voltage, two-dimensional paper electrophoresis to separate the oligonucleotides, followed by further nuclease digestions to determine their sequences. I was the last person in Harry's lab to use this classic method, which derived from the pioneering work of Fred Sanger and colleagues. I feel lucky to have this connection to the early days of molecular biology.

However, those classic techniques were challenging and had some risks. Keeping the $45 \times 60 \mathrm{~cm}$ sheet of DE- 81 paper from drying out during electrophoresis required immersing it in gallons of flammable Varsol, which is similar in composition to kerosene. I once checked the tank midway through an electrophoresis run and was horrified to see sparks jumping across a small tear in the paper where it crossed the top bar of the supporting rack. Fortunately, the lack of oxygen below the surface of the Varsol prevented ignition. Not everyone using this technique was so lucky; the Abelson lab at UCSD was gutted by a Varsol fire at around the same time.

Corresponding author: dabrow@wisc.edu

Article and publication date are at http://www.rnajournal.org/cgi/doi/ $10.1261 /$ rna.049668.115. Freely available online through the RNA Open Access option.
The project in Harry's lab resulted in my first publication, which was soon made obsolete by Danesh Moazed's and others' prolific studies using the new primer extension mapping method. Nevertheless, our JMB paper likely helped me get a postdoctoral fellowship, for which I applied before my $\mathrm{PhD}$ work was published. Another benefit of this influential undergraduate experience (beyond making many friends) was the exciting opportunity to meet several well-known molecular biologists, including Carl Woese, Joan Steitz, Masayasu Nomura, Christine Guthrie, and John Abelson. I thus became a convert to the RNA world early in my scientific career.

I moved on to UC San Diego for graduate training, where my first research rotation was in John Abelson's lab (postfire). There was a palpable tension amongst the post-docs, who were crowded into a small lab space and either trying to get yeast pre-mRNA splicing to work in vitro or engaged in similarly challenging projects. John's lab moved to Caltech the summer of my first year, and I chose Peter Geiduscheck's lab for my thesis work. There I spent five rewarding years studying feedback control of 5S rRNA gene transcription in yeast under Peter's attentive tutelage. This project initiated my interest in RNA-based control of DNA transcription, an interest that I am still pursuing. A highlight of this time was learning the basics of DNA supercoiling from Francis Crick in a small room with a handful of fellow firstyear graduate students. I also gave my first talk at a scientific conference, the 1985 CSHL meeting on the Molecular Biology of Yeast. There I met with Christine Guthrie and convinced her to accept me into her lab at UCSF for my postdoctoral research, which set me on the path to the aforementioned RNA article. Two other highlights were my marriage to Mary Ann Deese the summer after my first year of graduate school, and the birth of our first child in my last year at UCSD.

In Christine's lab I identified yeast U6 RNA using the techniques I had learned and developed as an undergrad and graduate student. When I compared the yeast U4 and U6 RNA sequences with those from humans, a conserved U4/ U6 secondary structure emerged. Splicing mechanism was a topic of intense interest in the RNA field at the time, and

(C) 2015 Brow This article, published in $R N A$, is available under a Creative Commons License (Attribution-NonCommercial 4.0 International), as described at http://creativecommons.org/licenses/by-nc/4.0/. 
it was exciting to contribute to the rapidly growing understanding of spliceosomal RNA structure. I attended the annual RNA Processing meeting every year from 1987 to 1995, except for 1989 when our second child was born and I started my faculty position. In 1994, this meeting was for the first time in Madison, Wisconsin instead of CSHL, and it was called the RNA Processing meeting of the RNA Society. It was, in effect, the 0th meeting of the RNA Society, the official first annual meeting being held in Madison in 1996 and covering a broader range of topics.

While still in Christine's lab I made the puzzling discovery that the human U4/U6 RNA complex, which was predicted to have a secondary structure nearly identical in stability to that of yeast, was in fact much less stable than the yeast complex. However, some preparations of the HeLa cell nuclear extract from which I isolated the U4/U6 complex contained a form of the complex with faster gel mobility that was much more stable, similar to the yeast U4/U6 RNA complex. This fast migrating, stable form of the complex was particularly abundant in a nuclear extract made in the Tjian lab for transcription studies, but virtually absent in nuclear extract made by Doug Black in Joan Steitz's lab for splicing studies. What could be different between these two U4/U6 complexes that so greatly affected their stability and migration?

With Brenda Bass' help, I tested my hypothesis that her newly discovered adenosine deaminase of RNA modified U4/U6 RNA, altering its stability and gel mobility; it did not. Using native gel electrophoresis I looked for an "RNA $\mathrm{X}$ " associated with the slow migrating form that might disrupt U4/U6 pairing. I did identify and sequence a new, comigrating RNA, but a phone conversation with Karen Montzka (now Wassarman) in Joan Steitz's lab revealed that it was identical to U11 RNA, which she had recently discovered. It co-migrated with U4/U6 complex due to similar size rather than association. We agreed I would not work on human U11, but would study the yeast homolog (as a side project). Only after Karen sent me oligonucleotide probes for the RNA, an expensive commodity back then, did it become apparent that there isn't a yeast U11! David Wassarman, also a student in Joan's lab, provided us with data that suggested the two forms of human U4/U6 were due to incomplete deproteinization of the U4/U6 snRNP, but that hypothesis didn't fit with my results. In fall 1989, I took this unsolved problem with me to my new faculty position at the University of Wisconsin-Madison.

Relegated to "back burner" status, the solution to this puzzle emerged only several years later. It turned out that the fast-migrating, stable form of human U4/U6 lacks the $3^{\prime}$ end of U6 RNA, presumably due to nucleolytic degradation during nuclear extract preparation. This 3' "tail" of U6 pairs with a central region of the RNA to form an intramolecular helix that destabilizes U4/U6 pairing, apparently by forming a Holliday junction-like structure that is susceptible to branch migration. We showed that either removal of the U6 $3^{\prime}$ tail or blocking its pairing with the central region of U6 with a DNA oligonucleotide increased the melting temperature of the human U4/U6 RNA complex by more than $15^{\circ} \mathrm{C}$. Furthermore, adding the blocking oligonucleotide to dissociated $\mathrm{U} 4$ and $\mathrm{U} 6 \mathrm{RNAs}$ at $30^{\circ} \mathrm{C}$ drives the spontaneous assembly of U4/U6 complex. The blocking oligo that pairs with the $3^{\prime}$ end of U6 mimics the $5^{\prime}$ end of U2 snRNA, which was previously shown by Alan Weiner's lab to base pair to the $3^{\prime}$ end of U6 RNA, forming U2/U6 Helix II. Thus, our finding suggested that U2/U6 Helix II stabilizes the human U4/U6 complex, consistent with the identification by David Wassarman and Joan Steitz of a U2/U6/U4 RNA complex in HeLa cell extract by psoralen crosslinking.

Our April 1995 paper revealed a property of RNA structure that was not well known, namely that formation of intramolecular base pairs can destabilize intermolecular pairing even when their formation is not mutually exclusive. In addition, it led us to propose the "telestem" of yeast U6 RNA and changed the way we think about the RNA conformational rearrangements that drive the pre-mRNA splicing cycle. Thus, the paper was, I think, an appropriate first article for the second issue of $R N A$, although I wish it had been the first article of the first issue! Harry Noller, John Abelson, and Joan Steitz all published articles in that second issue of RNA. I was gratified to have work from my lab published alongside that of leaders in the field who also were some of my mentors (official or unofficial). When I agreed to review my first manuscript for RNA later that year, Tom Cech actually called me on the phone to impress upon me the high standard they had set for accepting submitted papers. I felt very smug to be able tell him that I was quite aware of their high standards, since I had already published in the journal!

How has RNA science changed since 1995, when RNA first appeared? Both a lot and very little. The speed and precision with which we can generate sequencing data, mutant strains, and high-resolution macromolecular structures has increased enormously, resulting in a flood of new information. But answering tough mechanistic questions will always rely mostly on creative ideas and clever experimental design. We should always remember to take the time to reflect deeply on our findings, particularly the unexpected puzzles that spring up occasionally and can lead us to new ways of thinking about the biological processes we study.

I want to thank my mentors for providing opportunities and guidance, past and present members of my lab and department for their dedication and collegiality, the NIGMS, Searle Scholars and Shaw Scientist programs for funding, and my family, especially my wife Mary Ann, for their support and inspiration. I look forward to many more exciting discoveries, and papers in RNA! 

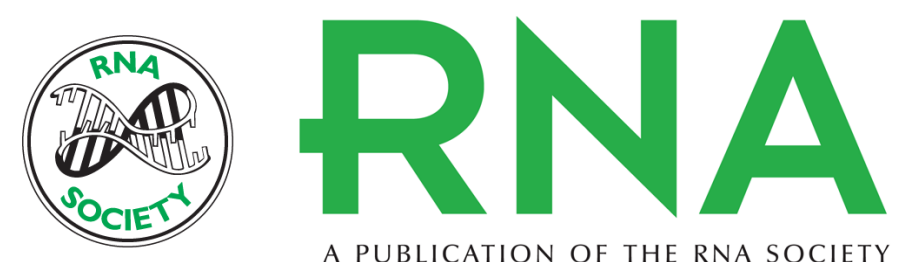

A PUBLICATION OF THE RNA SOCIETY

\section{An RNA mystery and its denouement}

David A. Brow

RNA 2015 21: 576-577

Open Access Freely available online through the RNA Open Access option.

Creative This article, published in $R N A$, is available under a Creative Commons License

Commons (Attribution-NonCommercial 4.0 International), as described at

License http://creativecommons.org/licenses/by-nc/4.0/.

Email Alerting Receive free email alerts when new articles cite this article - sign up in the box at the Service top right corner of the article or click here.

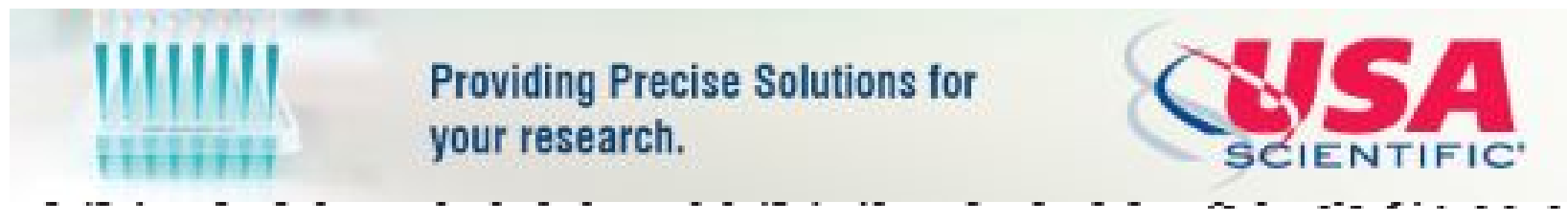

To subscribe to $R N A$ go to:

http://rnajournal.cshlp.org/subscriptions

(C) 2015 Brow; Published by Cold Spring Harbor Laboratory Press for the RNA Society 